\title{
Thermoanaerobacterium aciditolerans sp. nov., a moderate thermoacidophile from a Kamchatka hot spring
}

\author{
I. V. Kublanov, ${ }^{1}$ M. I. Prokofeva, ${ }^{1}$ N. A. Kostrikina, ${ }^{1}$ T. V. Kolganova, ${ }^{2}$ \\ T. P. Tourova, ${ }^{1}$ J. Wiegel ${ }^{3}$ and E. A. Bonch-Osmolovskaya ${ }^{1}$ \\ ${ }^{1}$ Institute of Microbiology, Russian Academy of Sciences, Prospekt 60-Letiya Oktyabrya 7/2, \\ Moscow 117312, Russia \\ ${ }^{2}$ Bioengineering Center, Russian Academy of Sciences, Prospect 60-Letiya Oktyabrya 7/1, \\ 117312 Moscow, Russia \\ ${ }^{3}$ Department of Microbiology, University of Georgia, Athens, GA, USA
}

\begin{abstract}
An anaerobic, moderately thermoacidophilic bacterium, strain $761-119^{\top}$, was isolated from an acidic hot spring in the Orange Field of the Uzon Caldera (Kamchatka, far-eastern Russia). Cells were spore-forming, Gram-positive rods, possessing one polar flagellum. Growth of strain $761-119^{\top}$ was observed between 37 and $68^{\circ} \mathrm{C}$ and in the $\mathrm{pH}^{20^{\circ} \mathrm{C}}$ range 3.2-7.1. No growth was observed within 5 days of incubation at or below $35^{\circ} \mathrm{C}$ and at or above $70^{\circ} \mathrm{C}$, as well as at or below $\mathrm{pH}^{20^{\circ} \mathrm{C}} 2.8$ and at or above $\mathrm{pH}^{20^{\circ} \mathrm{C}}$ 7.5. The optimal temperature and $\mathrm{pH}^{20^{\circ} \mathrm{C}}$ for growth were $55^{\circ} \mathrm{C}$ and $\mathrm{pH}^{20^{\circ} \mathrm{C}} 5.7$, respectively. A wide range of carbohydrates and polysaccharides were fermented, as well as peptides and proteinaceous substrates. The main products of glucose fermentation were acetate, ethanol, lactate, $\mathrm{H}_{2}$ and $\mathrm{CO}_{2}$. The DNA $\mathrm{G}+\mathrm{C}$ content was 34 $( \pm 0.5)$ mol\%. 16S rRNA gene sequence analysis indicated that strain 761-119 ${ }^{\top}$ belonged to the genus Thermoanaerobacterium. The level of $16 \mathrm{~S}$ rRNA gene sequence similarity with other Thermoanaerobacterium species was $86.5-97.8 \%$, with the only moderately acidophilic member of this genus, Thermoanaerobacterium aotearoense, being one of its closest relatives. DNA-DNA hybridization with $T$. aotearoense showed $33 \%$ relatedness. Thus, morphological (one polar flagellum) and physiological characteristics (lower $\mathrm{pH}$ limit of growth at $\mathrm{pH}^{20^{\circ} \mathrm{C}} 3.2$ compared with T. aotearoense) and $16 \mathrm{~S}$ rRNA gene sequence analyses revealed that strain $761-119^{\top}$ represents a novel species in the genus Thermoanaerobacterium, for which the name Thermoanaerobacterium aciditolerans sp. nov. is proposed, with the type strain $761-119^{\top}\left(=\mathrm{DSM} 16487^{\top}=\mathrm{VKM}\right.$ B-2363 ${ }^{\mathrm{T}}$ ).
\end{abstract}

Acidic hot environments are quite common throughout the world and include anthropogenic environments such as mines, coal and coal-refuse piles and self-heated compost heaps, as well as naturally heated volcanic habitats (Brock, 1986). Most of the known thermoacidophilic prokaryotes are either aerobic archaea or micro-organisms with different types of anaerobic respiration (Johnson, 1998; Wiegel \& Canganella, 2001). Thermoacidophiles with a fermentative type of metabolism are few in number. Examples are the facultatively anaerobic archaea of the genus Thermoplasma (Segerer et al., 1988) and the obligately anaerobic archaea of the genera Acidilobus (Prokofeva et al., 2000) and Caldisphaera (Itoh et al., 2003). The only anaerobic thermoacidophilic representative among the bacteria is

The GenBank/EMBL/DDBJ accession number for the 16S rRNA gene sequence of strain $761-119^{\top}$ is AY350594.
Thermoanaerobacterium aotearoense, a member of the Firmicutes, an obligately anaerobic heterotroph, a moderate thermophile and a moderate acidophile, which was isolated from a hot spring in New Zealand (Liu et al., 1996). Molecular and microbial analysis of the diversity of anaerobic thermophiles active at low $\mathrm{pH}$ in enrichment cultures obtained from terrestrial and deep-sea sources have revealed the presence of members of the genera Acidilobus, Thermoplasma, Thermoanaerobacter, Thermoanaerobacterium and Thermococcus (Prokofeva et al., 2005). Here, we report the detailed characterization of a novel thermoacidophilic bacterium belonging to the genus Thermoanaerobacterium, isolated from one of these enrichment cultures inoculated with water/sediment from the Uzon Caldera in Kamchatka (far-eastern Russia).

For enrichment of thermoacidophilic micro-organisms, the following basal medium was used $\left(\mathrm{g} \mathrm{l}^{-1}\right)$ : $\mathrm{NH}_{4} \mathrm{Cl}, 0.33 ; \mathrm{KCl}$, 
$0.33 ; \mathrm{KH}_{2} \mathrm{PO}_{4}, 0.33 ; \mathrm{CaCl}_{2} .2 \mathrm{H}_{2} \mathrm{O}, 0.33 ; \mathrm{MgCl}_{2} .6 \mathrm{H}_{2} \mathrm{O}, 0.33$; $\mathrm{NaCl}, 25.0$; yeast extract, 0.1; trace elements (Balch et al., 1979), $10 \mathrm{ml} \mathrm{l}^{-1}$; vitamins (Wolin et al., 1963) $10 \mathrm{ml} \mathrm{l}^{-1}$. Sucrose was added as substrate, at a final concentration of
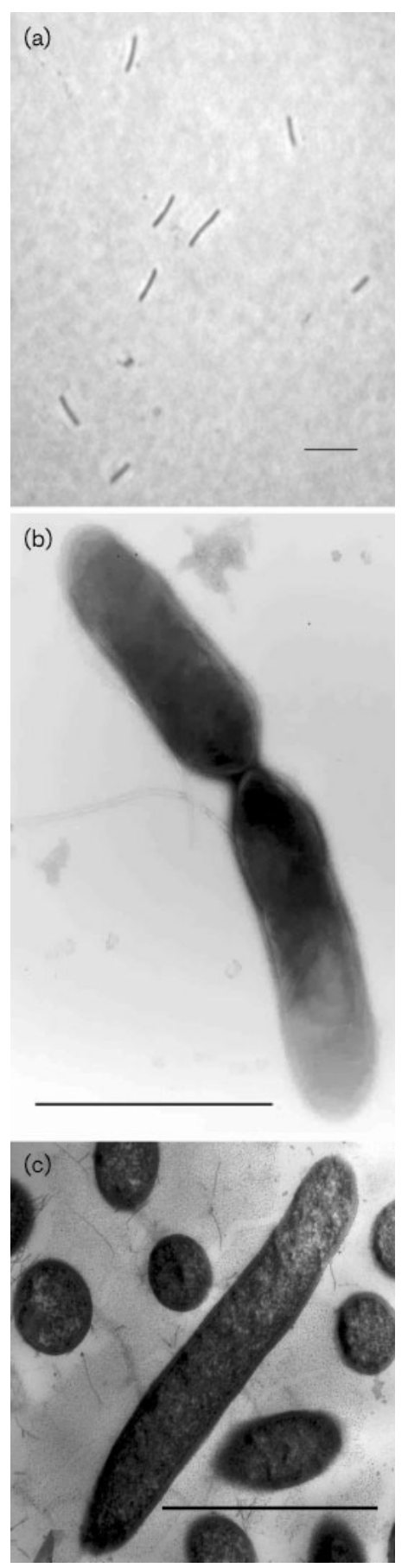

Fig. 1. Light and electron micrographs of strain $761-119^{\top}$. (a) Phase-contrast micrograph of exponentially growing cells. Bar, $10 \mu \mathrm{m}$. (b) Electron micrograph of negatively stained (BonchOsmolovskaya et al., 1990), exponentially growing cells. Bar, $1 \mu \mathrm{m}$. (c) Electron micrograph of a thin section (Bonch-Osmolovskaya et al., 1990) of exponentially growing cells. Bar, $1 \mu \mathrm{m}$.
$2 \mathrm{~g} \mathrm{l}^{-1}$. The medium was prepared anaerobically and reduced by adding $\mathrm{Na}_{2} \mathrm{~S}\left(600 \mathrm{mg} \mathrm{l}^{-1}\right)$. The medium was dispensed in $10 \mathrm{ml}$ portions in $15 \mathrm{ml}$ Hungate tubes; $\mathrm{CO}_{2}$ was used as the gas phase. The $\mathrm{pH}$ of the medium, measured at $20^{\circ} \mathrm{C}$ using a pH meter calibrated at $20^{\circ} \mathrm{C}$, was adjusted using anoxic $3 \mathrm{M} \mathrm{HCl}$. The $\mathrm{pH}$ and cultivation temperature used were approximately those from the sampling site. From the sample from Orange Field, Uzon Caldera, Kamchatka (coordinates $54^{\circ} 30.237^{\prime} \mathrm{N} 160^{\circ} 00.038^{\prime} \mathrm{E}, \mathrm{pH} 3.8,48^{\circ} \mathrm{C}$ ), an enrichment culture was obtained, growing at $60^{\circ} \mathrm{C}$ and $\mathrm{pH}^{20^{\circ} \mathrm{C}}$ 4.0. The dominating micro-organism from this culture was isolated from colonies from the highest positive dilution of the second round of serial dilutions into $1.5 \%$ agar shakes. Isolated colonies were transferred to liquid medium. One of the isolated strains was strain $761-119^{\mathrm{T}}$, described below.

Cells of strain $761-119^{\mathrm{T}}$ were spore-forming rods, $0.4 \mu \mathrm{m}$ wide and 3-12 $\mu \mathrm{m}$ long (Fig. 1a, b). Cells were motile, with one polar flagellum, and Gram-positive (Fig. 1c). The isolate grew over a temperature range of $37-68^{\circ} \mathrm{C}$, with an optimal growth temperature of $55^{\circ} \mathrm{C}$. The $\mathrm{pH}^{20}{ }^{\circ} \mathrm{C}$ range for growth was 3.2-7.1, with an optimum of $\mathrm{pH}^{20}{ }^{\circ} \mathrm{C}$ 5.7. The doubling time under optimal conditions was $1 \mathrm{~h}$. No growth was observed within 5 days of incubation at or below $\mathrm{pH}^{20^{\circ} \mathrm{C}} 2.8$ or $35^{\circ} \mathrm{C}$ and at or above $\mathrm{pH}^{20{ }^{\circ} \mathrm{C}} 7.5$ or $70^{\circ} \mathrm{C}$. After 2 days of growth at $\mathrm{pH}^{20{ }^{\circ} \mathrm{C}} 7.0$, a high degree of cell lysis occurred (after abundant growth), but not in medium with $\mathrm{pH}^{20^{\circ} \mathrm{C}}$ below 5.5. Growth of strain $761-119^{\mathrm{T}}$ occurred at $\mathrm{NaCl}$ concentrations of $0-3 \%$. No growth was observed at $4 \% \mathrm{NaCl}$. Isolate $761-119^{\mathrm{T}}$ was able to ferment various mono- and disaccharides including glucose, fructose, xylose, ribose, arabinose, galactose, maltose, sucrose and lactose. It also grew on yeast extract, peptone, sorbitol, starch, xylan, gelatin and albumin. Glycerol, ethanol, pyruvate and citrate did not support growth. Products of glucose

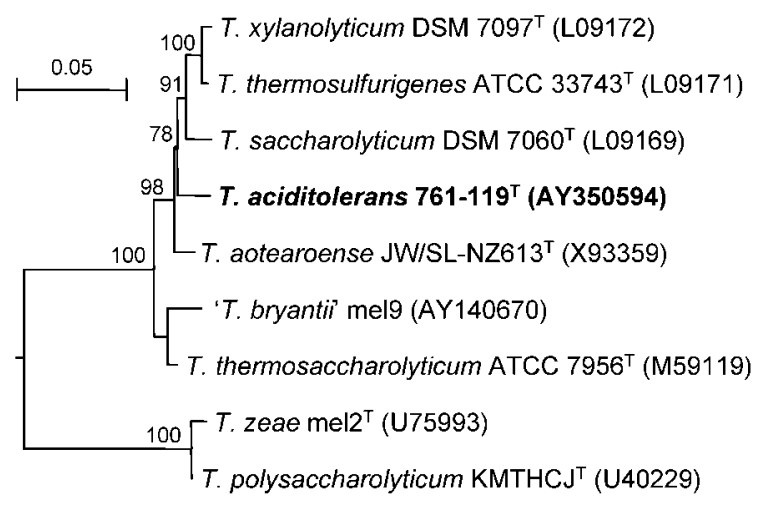

Fig. 2. Neighbour-joining tree based on $16 \mathrm{~S}$ rRNA gene sequences showing the phylogenetic positions of strain 761$119^{\top}$ and representatives of the genus Thermoanaerobacterium. Bootstrap values (expressed as percentages of 1000 replications) are shown at branch points. Bar, 0.05 substitutions per nucleotide position. 
Table 1. Characteristic features of strain $761-119^{\top}$ and Thermoanaerobacterium species

Taxa: 1, T. thermosulfurigenes (data from Lee et al., 1993); 2, T. xylanolyticum (Lee et al., 1993); 3, T. saccharolyticum (Lee et al., 1993); 4, T. zeae (Cann et al., 2001); 5, T. polysaccharolyticum (Cann et al., 2001); 6, T. aotearoense (Liu et al., 1996; this study); 7, strain 761-119 (this study). +, Positive; -, negative; NA, no data available; ND, not determined. All species utilize glucose, galactose and sucrose and form glucose, ethanol, acetate, $\mathrm{H}_{2}$ and $\mathrm{CO}_{2}$.

\begin{tabular}{|c|c|c|c|c|c|c|c|}
\hline Characteristic & 1 & 2 & 3 & 4 & 5 & 6 & 7 \\
\hline Spore formation & + & + & - & - & - & + & + \\
\hline Flagellation & Peritrichous & $\begin{array}{l}\text { Motile (no data } \\
\text { on flagellation) }\end{array}$ & Peritrichous & Peritrichous & $\begin{array}{c}\text { Flagellated } \\
\text { (no data on type } \\
\text { of flagellation) }\end{array}$ & Peritrichous & $\begin{array}{l}\text { Single } \\
\text { flagellum }\end{array}$ \\
\hline $\begin{array}{l}\text { Growth temperature } \\
\text { (min./opt./max.) }\left({ }^{\circ} \mathrm{C}\right)\end{array}$ & $55 / 60 / 75$ & $45 / 60 / 70$ & $45 / 60 / 68-70$ & NA/65-70/72 & NA/65-68/72 & $35 / 60-63 / 66$ & $37 / 55 / 68$ \\
\hline Growth pH (min./opt./max.) & $4.0 / 5.5-6.5 / 7.6$ & $5.0 / 6.0 / 7.5$ & $5.0 / 6.0 / 7.5$ & $3.9 / \mathrm{NA} / 7.9$ & $5.0 / 6.8-7.0 / 8.0$ & $3.8 / 5.2 / 6.8$ & $3.2 / 5.7 / 7.1$ \\
\hline \multicolumn{8}{|l|}{ Growth on: } \\
\hline Maltose & + & + & + & NA & NA & + & + \\
\hline Starch & + & NA & + & + & - & + & + \\
\hline Xylan & + & + & + & + & - & + & + \\
\hline Mannose & + & + & + & + & + & + & ND \\
\hline Arabinose & + & + & NA & + & + & + & + \\
\hline Lactose & - & + & + & + & + & + & + \\
\hline Fructose & $\mathrm{NA}$ & + & + & + & + & + & ND \\
\hline Citrate & NA & NA & NA & - & - & - & - \\
\hline Pyruvate & - & + & NA & + & + & - & - \\
\hline Pectin & + & $\mathrm{NA}$ & NA & - & - & + & $\mathrm{ND}$ \\
\hline Xylose & + & NA & + & $\mathrm{NA}$ & $\mathrm{NA}$ & + & + \\
\hline Ribose & NA & - & - & $\mathrm{NA}$ & NA & + & + \\
\hline Sorbitol & $\mathrm{NA}$ & NA & - & NA & $\mathrm{NA}$ & $\mathrm{NA}$ & + \\
\hline Glycerol & - & NA & NA & - & - & - & - \\
\hline Ethanol & NA & NA & NA & $\mathrm{NA}$ & NA & - & - \\
\hline \multicolumn{8}{|l|}{ Reduction of: } \\
\hline$S^{0}$ & NA & NA & NA & - & - & - & - \\
\hline Thiosulfate (product) & $+\left(S^{0}\right)$ & $+\left(S^{0}\right)$ & $+\left(S^{0}\right)$ & - & $+\left(\mathrm{H}_{2} \mathrm{~S}\right)$ & $+\left(S^{0}\right)$ & $+\left(S^{0}\right)$ \\
\hline Sulfite & $\begin{array}{l}\text { Inhibits } \\
\text { growth }\end{array}$ & NA & NA & - & - & NA & + \\
\hline Sulfate & - & NA & NA & NA & NA & - & - \\
\hline $\begin{array}{l}\text { Inhibitory concentration } \\
\text { of } \mathrm{NaCl}(\%)\end{array}$ & 2 & 1 & NA & NA & NA & NA & 4 \\
\hline \multicolumn{8}{|l|}{ Growth products } \\
\hline Formate & NA & NA & NA & + & + & - & ND \\
\hline Lactate & + & - & + & + & + & + & + \\
\hline DNA G + C content $(\mathrm{mol} \%)$ & 32.6 & 36.1 & 36 & 42 & 46 & $34.5-35$ & $34 \pm 0.5$ \\
\hline
\end{tabular}

fermentation (Bonch-Osmolovskaya \& Miroshnichenko, 1994) were acetate, ethanol and lactate, at a ratio of $14.5: 9: 1$, and $\mathrm{H}_{2}$ and $\mathrm{CO}_{2}$ (not quantified). Addition of thiosulfate $\left(2 \mathrm{~g} \mathrm{l}^{-1}\right)$ did not stimulate growth significantly; thiosulfate was reduced to molecular sulfur, which was deposited inside the cells. The addition of elemental sulfur $\left(10 \mathrm{~g} \mathrm{l}^{-1}\right)$ produced no stimulating effect; only trace amounts of hydrogen sulfide were detected. Sulfate $\left(2 \mathrm{~g} \mathrm{l}^{-1}\right)$ supplementation of the medium did not change the growth characteristics noticeably. Sulfate was not reduced; however, sulfite $(6 \mathrm{mM})$ was reduced to hydrogen sulfide and slightly inhibited growth (cell yield was 3.7-fold lower), concomitantly causing a change in cell morphology and in the ratio of fermentation products. The cells became much longer and formed long chains; the formation of ethanol increased 5.5-fold, from approximately $1.55 \times 10^{-8}$ to $8.5 \times 10^{-8} \mathrm{mmol}$ per cell.

DNA was isolated according to the method of Marmur (1961). The G + C content of the DNA was 34 ( \pm 0.5$) \mathrm{mol} \%$, as measured by thermal denaturation of the DNA (Marmur \& Doty, 1962).

The almost complete 16S rRNA gene sequence of strain $761-119^{\mathrm{T}}$ (1441 nt corresponding to nt 11-1469 of Escherichia coli numbering) was determined as described 
previously (Sokolova et al., 2002). Comparison of this $16 \mathrm{~S}$ rRNA gene sequence against the existing database using the BLAST program (http://www.ncbi.nlm.nih.gov/blast) revealed that strain $761-119^{\mathrm{T}}$ was a member of the large phylum Firmicutes, which includes the so-called low-G + Ccontent, Gram-positive bacteria. Within this subgroup, strain $761-119^{\mathrm{T}}$ fell within the genus Thermoanaerobacterium in the family Thermoanaerobacteriaceae in the order Thermoanaerobacteriales of the class Clostridia (Garrity et al., 2005). The 16S rRNA gene sequence similarity values between strain $761-119^{\mathrm{T}}$ and the type strains of Thermoanaerobacterium species with validly published names were in the range $86.5-97.8 \%$. The phylogenetic position of isolate $761-119^{\mathrm{T}}$ was revealed by constructing a 16S rRNA gene sequence phylogenetic tree (Fig. 2), employing TREECON (Van De Peer \& De Wachter, 1994) and using Jukes and Cantor corrections (Jukes \& Cantor, 1969). This analysis showed that the $16 \mathrm{~S}$ rRNA gene sequence of isolate $761-119^{\mathrm{T}}$ had $<97 \%$ similarity with those of all species of the genus Thermoanaerobacterium with one exception - the type strain of the most closely related species T. aotearoense (Liu et al., 1996), with $97.8 \%$ sequence similarity. This correlation was also mirrored in a comparison of phenotypic characteristics of isolate $761-119^{\mathrm{T}}$ and species of the genus Thermoanaerobacterium (Table 1). Although T. aotearoense and isolate $761-119^{\mathrm{T}}$ used similar growth substrates and were both moderate thermoacidophiles, they differed in that strain $761-119^{\mathrm{T}}$ had one polar flagellum and a lower $\mathrm{pH}$ limit of $\mathrm{pH}^{20}{ }^{\circ} \mathrm{C} 3.2$, while $T$. aotearoense had peritrichous flagellation and an acidic $\mathrm{pH}$ limit for growth of 3.8. DNA-DNA hybridization between strain $761-119^{\mathrm{T}}$ and T. aotearoense was carried out using the method of Marmur (1961) and yielded 33\% relatedness, indicating that the two strains belonged to different species. Thus, isolate $761-119^{\mathrm{T}}$ is proposed to represent the type strain of a novel species, for which the name Thermoanaerobacterium aciditolerans sp. nov. is proposed.

\section{Description of Thermoanaerobacterium aciditolerans sp. nov.}

Thermoanaerobacterium aciditolerans (a.ci.di.tol'er.ans. N.L. neut. n. acidum an acid; L. pres. part. tolerans tolerating; N.L. part. adj. aciditolerans acid-tolerating).

Cells are rod-shaped, motile and spore-forming, $0.4 \mu \mathrm{m}$ in diameter and 3-12 $\mu \mathrm{m}$ long, with Gram-positive cell walls and one flagellum. Obligate anaerobe. Moderate thermophile growing between 37 and $68^{\circ} \mathrm{C}$, with an optimum at $55^{\circ} \mathrm{C}$ (no growth within 5 days at or below $35^{\circ} \mathrm{C}$ and at or above $70^{\circ} \mathrm{C}$ ). Moderate acidophile growing in the $\mathrm{pH}^{20^{\circ} \mathrm{C}}$ range $3.2-7.1$, with an optimum $\mathrm{pH}^{20^{\circ} \mathrm{C}}$ at 5.7 (no growth at or below $\mathrm{pH}^{20{ }^{\circ} \mathrm{C}} 2.8$ and at or above $\mathrm{pH}^{20{ }^{\circ} \mathrm{C}} 7.5$ ), and at $\mathrm{NaCl}$ concentrations of $0-3 \%$ (no growth at $4 \% \mathrm{NaCl}$ ). Grows by fermentation of glucose, maltose, fructose, sucrose, lactose, xylose, ribose, arabinose, galactose, yeast extract, sorbitol, starch, xylan, gelatin and albumin. Glycerol, ethanol, pyruvate and citrate are not utilized. Fermentation products are acetate, ethanol, lactate,
$\mathrm{H}_{2}$ and $\mathrm{CO}_{2}$. Thiosulfate is reduced to $\mathrm{S}^{0}$, which is deposited inside the cells. Sulfite is reduced to sulfide. The DNA G + C content is $34 \quad( \pm 0.5) \mathrm{mol} \%$ (thermal denaturation method).

The type strain is $761-119^{\mathrm{T}}\left(=\mathrm{DSM} 16487^{\mathrm{T}}=\mathrm{VKM}\right.$ B$2363^{\mathrm{T}}$ ), isolated from a hydrothermal vent in the Orange Field, Uzon Caldera (Kamchatka, far-eastern Russia).

\section{Acknowledgements}

This work was supported by the programmes of the Russian Academy of Sciences 'Molecular and Cell Biology' and 'Origin and Evolution of Biosphere', by RFBR grant \# 05-04-48058, as well as by NSF-funded research grant 'Microbial Observatory Kamchatka, an International Interdisciplinary Research Project' (NSF MCB-02238407).

\section{References}

Balch, W. E., Fox, G. E., Magrum, G. E., Woese, G. E. \& Wolfe, R. S. (1979). Methanogens: reevaluation of a unique biological group. Microbiol Rev 43, 260-296.

Bonch-Osmolovskaya, E. A. \& Miroshnichenko, M. L. (1994). The influence of molecular hydrogen and elemental sulfur on the metabolism of extremely thermophilic archaea of genus Thermococcus. Microbiology (English translation of Mikrobiologiia) 63, 433-437.

Bonch-Osmolovskaya, E. A., Sokolova, T. G., Kostrikina, N. A. \& Zavarzin, G. A. (1990). Desulfurella acetivorans gen. nov., sp. nov. - a new thermophilic sulfur-reducing eubacterium. Arch Microbiol 153, 151-155.

Brock, T. D. (1986). Notes on the ecology of thermophilic archaebacteria. Syst Appl Microbiol 7, 213-215.

Cann, I. K. O., Stroot, P. G., Mackie, K. R., White, B. A. \& Mackie, R. I. (2001). Characterization of two novel saccharolytic, anaerobic thermophiles, Thermoanaerobacterium polysaccharolyticum sp. nov. and Thermoanaerobacterium zeae sp. nov., and emendation of the genus Thermoanaerobacterium. Int J Syst Evol Microbiol 51, 293-302.

Garrity, G. M., Bell, J. A. \& Lilburn, T. G. (2005). Taxonomic outline of the prokaryotes. In Bergey's Manual of Systematic Bacteriology, 2nd edn. New York: Springer. http://141.150.157.80/bergeysoutline/main.htm

Itoh, T., Suzuki, K., Sanchez, P. C. \& Nakase, T. (2003). Caldisphaera lagunensis gen. nov., sp. nov., a novel thermoacidophilic crenarchaeote isolated from a hot spring at Mt Maquiling, Philippines. Int J Syst Evol Microbiol 53, 1149-1154.

Johnson, D. B. (1998). Biodiversity and ecology of acidophilic microorganisms. FEMS Microbiol Ecol 27, 307-317.

Jukes, T. H. \& Cantor, C. R. (1969). Evolution of protein molecules. In Mammalian Protein Metabolism, pp. 21-32. Edited by H. N. Munro. New York: Academic Press.

Lee, Y. E., Jain, M. K., Lee, C., Lowe, S. E. \& Zeikus, J. G. (1993). Taxonomic distinction of saccharolytic thermophilic anaerobes: description of Thermoanaerobacterium xylanolyticum gen. nov., sp. nov., and Thermoanaerobacterium saccharolyticum gen. nov., sp. nov.; reclassification of Thermoanaerobium brockii, Clostridium thermosulfurogenes, and Clostridium thermohydrosulfuricum E100-69 as Thermoanaerobacter brockii comb. nov., Thermoanaerobacterium thermosulfurigenes comb. nov., and Thermoanaerobacter thermohydrosulfuricus comb. nov., respectively; and transfer of Clostridium thermohydrosulfuricum $39 \mathrm{E}$ to Thermoanaerobacter ethanolicus. Int J Syst Bacteriol 43, 41-51. 
Liu, S.-Y., Rainey, F. A., Morgan, H. W., Mayer, F. \& Wiegel, J. (1996). Thermoanaerobacterium aotearoense sp. nov., a slightly acidophilic, anaerobic thermophile isolated from various hot springs in $\mathrm{New}$ Zealand, and emendation of the genus Thermoanaerobacterium. Int J Syst Bacteriol 46, 388-396.

Marmur, J. (1961). A procedure for the isolation of deoxyribonucleic acid from microorganisms. J Mol Biol 3, 208-218.

Marmur, J. \& Doty, P. (1962). Determination of the base composition of deoxyribonucleic acid from its thermal denaturation temperature. J Mol Biol 5, 109-118.

Prokofeva, M. I., Miroshnichenko, M. L., Kostrikina, N. A., Chernyh, N. A., Kuznetsov, B. B., Tourova, T. P. \& Bonch-Osmolovskaya, E. A. (2000). Acidilobus aceticus gen. nov., sp. nov., a novel anaerobic thermoacidophilic archaeon from continental hot vents in Kamchatka. Int J Syst Evol Microbiol 50, 2001-2008.

Prokofeva, M. I., Kublanov, I. V., Nercessian, O., Tourova, T. P., Kolganova, T. V., Lebedinsky, A. V., Bonch-Osmolovskaya, E. A., Spring, S. \& Jeanthon, C. (2005). Cultivated anaerobic acidophilic/ acidotolerant thermophiles from terrestrial and deep-sea hydrothermal habitats. Extremophiles 9, 437-448.

Segerer, A., Langworthy, T. A. \& Stetter, K. O. (1988). Thermoplasma acidophilum and Thermoplasma volcanium sp. nov. from solfatara fields. Syst Appl Microbiol 10, 161-171.

Sokolova, T. G., Kostrikina, N. A., Chernyh, N. A., Tourova, T. P., Kolganova, T. V. \& Bonch-Osmolovskaya, E. A. (2002). Carboxydocella thermautotrophica gen. nov., sp. nov., a novel anaerobic, CO-utilizing thermophile from a Kamchatkan hot spring. Int J Syst Evol Microbiol 52, 1961-1967.

Van De Peer, Y. \& De Wachter, R. (1994). TREECON for Windows: a software package for the construction and drawing of evolutionary trees for the Microsoft Windows environment. Comput Appl Biosci 10, 569-570.

Wiegel, J. \& Canganella, F. (2001). Extreme thermophiles. In Encyclopedia of Life Sciences, article 392. Chichester: Wiley. http://www.els.net

Wolin, E. A., Wolin, M. J. \& Wolfe, R. S. (1963). Formation of methane by bacterial extracts. J Biol Chem 238, 2882-2888. 